\title{
ABSOLUTE DETERMINATION OF RIGHT ASCENSIONS OF STARS AT HIGH GEOGRAPHICAL LATITUDE DURING THE POLAR NIGHT
}

\author{
G. M. PETROV \\ Nikolajev Observatory, U.S.S.R.
}

\begin{abstract}
It is proposed that transit observations on the islands of Spitsbergen $\left(\varphi=78^{\circ}\right)$ and Ross $\left(\varphi=-78^{\circ}\right)$ be organised in order to determine absolute right ascension by observing continually throughout the polar night.
\end{abstract}

In determinations of absolute right ascensions of celestial bodies the most important tasks are derivations of the absolute instrumental azimuth and smoothing the R.A. of clock stars from the initial catalogue.

A determination of the absolute azimuth (or Bessel's $n$ ), according to the Pulkovo method, is made from observations of the same star at two culminations with the time interval of 12 hours, i.e. under quite unequal conditions. Meteorological factors are known to influence on the refraction and also the instrument. Since the precise allowance for these influence has not been achieved as yet, the observational results may be expected to be distorted by a systematic error varying during the year.

The above difficulties could be reduced if observations be made during the whole polar night at the geographical latitude $\varphi \approx 80^{\circ}$. At this latitude, a night lasts up to 90 days, most of the stars being observable in both culminations and meteorological characteristics being unchanged with the 24-h period. We suppose that under these conditions more precise results could be obtained.

The best place for such observations in the northern hemisphere seems to be Spitsbergen island. The Gulf Stream has a beneficial influence on the climate of the island. For example, in one settlement, Piramida, $\left(\varphi=+78^{\circ}\right)$ during last 7 years, there were 28 cloudless days (on the average) within one polar night. The mean value of the air temperature was about $-20.3^{\circ} \mathrm{C}$ and the wind speed in clear weather did

TABLE I

\begin{tabular}{lll}
\multicolumn{3}{c}{$\begin{array}{c}\text { Proportion of cloudless days and mean } \\
\text { monthly temperatures at McMurdo } \\
\text { 10 years }\end{array}$} \\
\hline Month & $\begin{array}{c}\text { Percent of } \\
\text { clear days }\end{array}$ & $\begin{array}{c}\text { Temperature } \\
\left({ }^{\circ} \mathrm{C}\right)\end{array}$ \\
\hline April & $17.1 \%$ & -21.7 \\
May & 28.3 & -22.9 \\
June & 26.6 & -24.1 \\
July & 34.7 & -26.5 \\
August & 30.9 & -27.3 \\
\hline
\end{tabular}


not exceed $2 \mathrm{~m} \mathrm{~s}^{-1}$. In the southern hemisphere the village of McMurdo on the Ross island $\left(\varphi=-78^{\circ}\right)$ is apparently also quite a suitable place. The characteristics of this place are given in Table $\mathrm{I}$.

At Piramida and McMurdo, snow cover is absent in summer and an astronomical pavilion can be built on permanent frost. Thus the winds, blowing with the rate of $40 \mathrm{~m} \mathrm{~s}^{-1}$ though very rare, would not destroy it.

In the near future we intend to commence the FK4 star observations with the reversible photoelectric transit instrument on Spitsbergen. According to the program the observations. will last during 3 polar nights; the stars will be observed not less than 10 times in each culmination. 